\title{
KOLEKTIVNA ZAŠTITA POTROŠAČA U CRNOJ GORI - DE LEGE LATA I DE LEGE FERENDA -
}

\begin{abstract}
Apstrakt: Autor u radu obrađuje kolektivnu zaštitu potrošača u Crnoj Gori. Posebna pažnja posvećena je istorijskom nastanku i razvoju kolektivne zaštite u crnogorskom pravu uopšte. Razvoj ovog instituta ispituje se u svijetlu dugogodišnjeg procesa regulatorne nadgradnje crnogorskog pravnog sistema u pristupnim pregovorima u pregovaračkom poglavlju posvećenom zaštiti potrošača i zdravlja, s obzirom na činjenicu da je ideja kolektivne zaštite posljedica usaglašavanja nacionalnog zakonodavstva u ovoj oblasti. Autor je u radu dao i prikaz slučajeva kolektivne zaštite u crnogorskom pravu. Postojeći zakonski okvir je prezentovan, kao i najnoviji predlog direktive Evropske unije u ovoj oblasti, koje će značajno izmijeniti sistem kolektivne zaštite uspostavljen na nivou Evrope. Na kraju, date su preporuke za izmjenu crnogorskog prava, ne samo u cilju harmonizacije nacionalnog zakonodavstva već u cilju stvaranja djelotvornih mehanizama da ovaj vid zaštite ostvari svoju osnovnu svrhu.
\end{abstract}

Ključne riječi: kolektivna zaštita potrošača, kolektivna sudska zaštita, kolektivna vansudska zaštita.

\section{UVOD}

Zaštita potrošača je pojam koji je tekovina novijeg crnogorskog zakonodavstva. ${ }^{1}$ Tačnije, može se reći da je ova grana prava nastala i prije otvaranja pristupnih pregovora, mada se ozbiljnijem utvrđivanju pravila u ovoj oblasti pristupilo neposredno pred otvaranje pregovora. Danas možemo reći da je Crna Gora postigla značajan napredak u pristupnim pregovorima sa Evropskom unijom. ${ }^{2}$ I prije nego što su pregovori u Poglavlju 28 - Zaštita potrošača i zdravlja otvoreni u decembru 2014. godine, Crna Gora je, u skladu sa preuzetim obavezama u

* Docent na Pravnom fakultetu Univerziteta Crne Gore

e-mail: nikolad@ucg.ac.me

1 Prvi zakon u ovoj oblasti bio je Zakon o zaštiti potrošača, Sl. list SRJ, br. 37/02 (u daljem tekstu: ZZP 2002). Nakon ovog teksta uslijedio je Zakon o zaštiti potrošača, Sl. list RCG, br. 26/07, 40/11, 35/13, 1/14, 14/14 (u daljem tekstu: ZZP 2007).

2 Od juna 2012. godine (početak pristupnih pregovora), Crna Gora je otvorila pregovore u 34 od ukupno 35 pregovaračkih poglavlja i privremeno zatvorila pregovore u tri poglavlja. Nije otvoreno jedino poglavlje posvećeno konkurenciji, iako su ispunjeni svi početni kriterijumi. Otvaranje ovog poglavlja bilo je najavljeno za kraj juna 2020. godine. 
ovom procesu, kao država kandidat preduzimala značajne napore na usaglašavanju svog nacionalnog zakonodavstva sa pravom Evropske unije u oblasti zaštite potrošača. U ovom procesu, u konvencionalni pravni sistem se često uvode nove i ovom sistemu nespecifične ustanove i principi, što predstavlja konstantni izazov ne samo za zakonodavca već i za crnogorsku laičku i stručnu javnost, s obzirom na uvedene koncepte i moguće probleme u njihovoj primjeni.

Osnovni aspekti koncepta kolektivne zaštite potrošača u pravu Evropske unije dijelom su obuhvaćeni odgovarajućim reformskim procesima koje sprovode nadležne institucije i ekspertska tijela u Crnoj Gori. Najznačajniji instrument transpozicije različitih aspekata kolektivne zaštite potrošača je svakako Zakon o zaštiti potrošača, ${ }^{3}$ na koji se naslanjaju i određeni drugi zakonski i podzakonski akti.

S obzirom na to da je kolektivna zaštita u crnogorskom pravu sektorski regulisana, tj. za razliku od nekih zemalja bivše Jugoslavije ${ }^{4}$ nema pravila o kolektivnoj zaštiti horizontalnih karaktera, u radu će biti dat i pregled pravila o kolektivnoj zaštiti u drugim oblastima prava u crnogorskom zakonodavstvu. Sektorske oblike zaštite jasno karakteriše snažan uticaj evropskih pravila, kao i značajan stepen usklađenosti crnogorskog prava iako su, u suštini, pored potrošačkog prava prisutni samo još u domenu zaštite od diskriminacije.

U nastavku će biti predstavljen crnogorski sistem zaštite kolektivnih interesa potrošača, primjena pravila u periodu od ustanovljavanja ovog oblika zaštite do trenutka pisanja ovog rada. Takođe, imajući u vidu obavezu usaglašavanja nacionalnog zakonodavstva sa novim direktivama u ovoj oblasti, skorije izmjene u kolektivnoj zaštiti će biti analizirane u svijetlu mogućih rješenja u crnogorskom zakonodavstvu.

\section{PRIKAZ RAZVOJA SISTEMA ZAŠTITE POTROŠAČA U CRNOJ GORI}

U prilog tvrdnji da je zaštita potrošača tekovina novijeg zakonodavstva, govori i činjenica da do donošenja prvog Zakona o zaštiti potrošača 2002. godine, nacionalni propisi nijesu poznavali termin potrošač, kao ni tada važeći Zakon o obligacionim odnosima. ${ }^{5}$ Nakon donošenja ZZP 2007, uslijedilo je donošenje čitavog niza zakonskih i podzakonskih pravila u funkciji zaštite potrošača u Crnoj Gori. Ipak, kolektivna zaštita je našla svoje mjesto tek u ZZP 2014, kada je ovaj koncept po prvi put uveden u crnogorsko pravo.

3 Zakon o zaštiti potrošača, Sl. list CG, br. 2/14, 43/15, 70/17 i 67/19 (u daljem tesktu: ZZP 2014).

4 U Hrvatskoj (vid. Pavlović, M., 2015, Značaj tužbe za kolektivnu zaštitu interesa i prava, Zbornik radova Pravnog fakulteta u Splitu, 3, Pravni fakultet Univerziteta u Splitu, str. 799818) i doskora u Srbiji (vid. Karanikić, M., 2014, Kolektivna zaštita potrošača u srpskom pravu, Zbornik radova Pravnog fakulteta u Zenici, 14, Pravni fakultet Univerziteta u Zenici, str. 58-83).

5 Zakon o obligacionim odnosima, Sl. list SFRJ, br. 29/78, 39/85, 45/89 i 57/89, Sl. list SRJ, br. 31/93 i Sl. list SCG, br. 1/03. 


\subsection{POJAM KOLEKTIVNE ZAŠTITE U CRNOGORSKOM PRAVU}

Mehanizam kolektivne zaštite potrošača uređen je odredbama Glave I Četvrtog dijela novog ZZP 2014. donesenog u skladu sa nacionalnim programom za usklađivanje zakonodavstva. ${ }^{6}$ Ovim zakonom izvršeno je usklađivanje sa većim brojem direktiva iz oblasti zaštite potrošača, $s$ tim da je usklađivanje $u$ oblasti kolektivne zaštite potrošača vršeno sa Direktivom o sudskim nalozima za zaštitu interesa potrošača. ${ }^{7}$ Iako u vrijeme donošenja ovog zakona nije postojala jasna obaveza Crne Gore za uvođenje novog mehanizma zaštite potrošača, Preporuka Komisije o zajedničkim načelima o kolektivnim zahtjevima za zabranu postupanja i kolektivnim zahtjevima za naknadu štete, ${ }^{8} \mathrm{u}$ vezi s povredama prava koja su garantovana pravom Evropske unije, našla se na listi dokumenata koje su predlagači teksta imali u vidu kada su pripremali tekst ovog zakona.

Pojam kolektivne zaštite odredićemo prema idejama i preporukama datim $\mathrm{u}$ ovom dokumentu, s obzirom na to da je u vrijeme donošenja ZZP 2014. ovaj dokument bio osnovna smjernica za uvođenje novog oblika zaštite interesa potrošača u crnogorsko pravo.

Ipak, i pored toga što je osnovni cilj Preporuke promovisanje ideje jedinstvenog, tj. horizontalnog regulatornog okvira kolektivne zaštite na nacionalnom nivou, ${ }^{9}$ koji bi imao zajedničke ključne principe u svim državama članicama Evropske unije, crnogorski zakonodavac je pristupio sektorskom regulisanju kolektivne zaštite, u ZZP 2014, predviđajući određene mehanizme kolektivne zaštite samo u oblasti zaštite potrošača.

Dakle, crnogroski zakonodavac je optirao da sistem kolektivne zaštite uredi samo u oblasti potrošačkih prava, a ne i u oblasti drugih prava koja su ustanovljena pravom Evropske unije ili drugim oblastima u kojima bi benefiti kolektivne zaštite mogli značajno da utiču na ostvarivanje garantovanih prava. Ipak, jasno je da nije postojala obaveza nacionalnog zakonodavca da predvidi ovaj pristup, jer i sam instrument koji sadrži određena pravila ima formu preporuke, tako da je jasno da se nisu bili stekli uslovi da se ovo pitanje rješava obaveznim instrumentima za usaglašavanje nacionalnih zakonodavstava. $\mathrm{U}$ tom smislu, fokus će nam biti na usaglašenosti rješenja sadržanih u ZZP 2014. sa tekstom Preporuke, budući da ne postoji regulatorni okvir horizontalnog karaktera u crnogorskom pravu.

6 Vlada Crne Gore, 2013, Program pristupanja Evropskoj uniji od 2014. do 2018. godine.

7 Direktiva 2009/22/EZ Evropskog parlamenta i Vijeća od 23. aprila 2009. o sudskim nalozima za zaštitu interesa potrošača.

8 Preporuka 2013/396/EZ od 11. juna 2013. o zajedničkim načelima o kolektivnim zahtjevima za zabranu postupanja i kolektivnim zahtjevima za naknadu štete, u vezi s povredama prava koja su garantovana pravom Evropske unije (u daljem tekstu: Preporuka).

9 Fairgrieve, D. et al., 2018, Collective Redress Mechanisms in Consumer Protection in the European Union and South East Europe: Comparative Study, Deutsche Gesellschaft für Internationale Zusammenarbeit (GIZ) GmbH, p. 25. 
Zakonodavac je odabrao da zaštitu postavi na jedinstvenim osnovama, ne praveći razliku između specifičnih oblika potrošačkih ugovora. ${ }^{10}$

Iako je u prvom dijelu člana posebno naglašena primjena ovog oblika zaštite $\mathrm{u}$ slučaju upotrebe nepoštenih ugovornih odredaba i poslovne prakse, ipak se u drugom dijelu istog stava pruža zaštita protiv trgovca koji „na bilo koji drugi način krši prava potrošača utvrđena ovim ili drugim zakonom, čime narušava kolektivne interese potrošača". ${ }^{11}$

Najznačajniji dio istog stava ukazuje na oblik kolektivne zaštite koji je dozvoljen u crnogorskom pravu. Naznakom da se kolektivna zaštita pruža „za prestanak tih radnji” kojima se krše prava potrošača, jasno se ukazuje da je u crnogorskom pravu primijenjena preventivna zaštita, čime je zaštita pružena samo u smislu zabrane daljeg ponašanja koje sud ocijeni kao nedozvoljeno. Propisujući ovaj vid zaštite kao jedini mogući u crnogorskom pravu, jasno je da zakonodavac nije predvidio mehanizme za kompenzatornu zaštitu potrošača, u smislu kolektivne tužbe za naknadu štete. Dakle, na samom početku moramo konstatovati da u nastavku teksta neće biti govora o usaglašenosti nacionalnog zakonodavstva sa III dijelom Preporuke, s obzirom na to da se ovim dijelom predviđaju standardi koji se isključivo odnose na oblik kompenzatorne zaštite.

Ukoliko posmatramo usaglašenost nacionalnog zakonodavstva sa ovim instrumentom u dijelu u kojem je zakonodavac odabrao da vrši usaglašavanje, ne može se reći da je usaglašenost postignuta u visokom obimu. U dijelu Preporuke koji je posvećen pravilima koja se smatraju zajedničkim za kompenzatornu i preventivnu zaštitu (IV dio) i onom koji je posvećen posebnim pravilima za preventivnu zaštitu ( $\mathrm{V}$ dio), jasno su vidljiva odstupanja.

Tako, ZZP 2014. sadrži odredbe o aktivnoj legitimaciji, pitanju provjere dopuštenosti, informisanja javnosti o pokrenutim i okončanim postupcima, dodjeljivanja naknade troškova postupka stranci koja uspije u sporu, kao i pravila o sporovima prekogranične prirode. ${ }^{12}$ Ipak, neusaglašenost postoji u dijelu koji se odnosi na pravila o finansiranju postupka po kolektivnoj tužbi strane tužioca, odnosno trećih lica. ${ }^{13}$

Kako je odredbama ZZP 2014. samo predviđena shodna primjena propisa kojim se reguliše parnični postupak, ${ }^{14}$ izostala su pravila koja se odnose na pitanje ubrzanja i pojednostavljenja postupaka kolektivne zaštite, kao i pitanje obezbjeđenja efikasnije primjene sudskih odluka kojima se prihvata tužbeni zahtjev. $^{15}$ Jasno je da se ovo rješenje ne može smatrati dovoljnim za postizanje pune usaglašenosti nacionalnog zakonodavstva sa odredbama Preporuke.

10 Savković, V., Dožić, N., 2018, Collective Redress in Consumer Protection in Montenegro, Collective Redress Mechanisms in Consumer Protection in the European Union and South East Europe - Comparative Study, GIZ, Skopje, p. 306.

Član 118. stav 2. ZZP 2014.

12 Vid. tač. 4-13. Preporuke.

13 Vid. tač. 14-16. Preporuke.

14 Član 129. ZZP 2014.

15 Vid. tač. 19. i 20. Preporuke. 
Najmanje sporan za usaglašavanje bio je, čini se, dio koji se odnosi na uspostavljanje Registra kolektivnih tužbi za zaštitu prava potrošača, tako da je usklađivanje u ovoj oblasti izvršeno uspostavljanjem registra kolektivnih tužbi i presuda koji vodi Ministarstvo, kao i obaveza nadležnih organa koje mogu biti od značaja za valjano vođenje ovakvog registra. ${ }^{16}$

\subsection{POSTUPAK PO TUŽBI ZA KOLEKTIVNU ZAŠTITU POTROŠAČA U CRNOGORSKOM PRAVU}

Postupak za zaštitu kolektivnih interesa potrošača može se pokrenuti zbog upotrebe nepoštenih ugovornih odredaba, poslovne prakse ili bilo kojeg drugog oblika kršenja prava potrošača utvrđenih tim ili drugim zakonom koje istovremeno predstavlja i narušavanje njihovih kolektivnih interesa. Pitanja aktivne i pasivne legitimacije u ovom sporu od posebnog su značaja, s obzirom na krug lica koja se mogu pojaviti kao nosioci ovih uloga u sporu.

Značajan iskorak učinjen je prilikom uređivanja pitanja aktivne legitimacije u ZZP 2014, jer je aktivna legitimacija u sporu data i ministarstvu nadležnom za sprovođenje ovog zakona, ${ }^{17}$ kao i drugim ministarstvima i organima državne uprave koji imaju nadležnosti u sprovođenju ovog zakona. ${ }^{18}$ Osim toga, aktivno su legitimisane i organizacije potrošača, komorska i interesna udruženja trgovaca. Ispunjenje dodatnih uslova predviđeno je samo u slučaju kada se kao podnosilac tužbe javlja udruženje potrošača, što cijeni Ministarstvo i objavljuje listu organizacija koje se u tekućoj godini mogu pojaviti kao podnosioci kolektivnih tužbi. ${ }^{19}$

U tom postupku, Ministarstvo cijeni ispunjenost tri uslova. Prvo, organizacije moraju biti u evidenciji organizacija potrošača i saveza organizacija potrošača (koju vodi Ministarstvo) najmanje godinu dana. Zakon uređuje posebne uslove za upis u ovu evidenciju. ${ }^{20}$ Drugo, organizacija potrošača mora imati angažovanog najmanje jednog diplomiranog pravnika, sa najmanje tri godine radnog iskustva. Treće, organizacija mora stvarno da djeluje i ima ostvarene rezultate u oblasti zaštite interesa potrošača, koji se dokazuju godišnjim izvještajem o radu koje su registrovane organizacije potrošača dužne redovno dostavljati nadležnom ministarstvu najkasnije do 31. marta tekuće za prethodnu godinu. ${ }^{21}$ Naravno, ZZP 2014. uredio je i uslove i postupak oduzimanja ovlašćenja za pokretanje kolektivne tužbe. ${ }^{22}$

16 Član 127. ZZP 2014.

17 Prema organizaciji državne uprave i Vlade Crne Gore, ministarstvo nadležno za sprovođenje ZZP 2014. je Ministarstvo ekonomije.

18 Slično rješenje sadrži i zakon Srbije. Vid. Babović, B., 2014, Zaštita kolektivnih interesa potrošača, Anali Pravnog fakulteta u Beogradu, 2, str. 227.

19 Ministarstvo ekonomije je obavezno da do 30. aprila tekuće godine utvrdi i objavi na svojoj internet prezentaciji listu organizacija potrošača koje su ovlašćene za podnošenje tužbe za zaštitu kolektivnih interesa potrošača, kao i listu organizacija potrošača kojima su ova ovlašćenja oduzeta.

20 Vid. član 165. ZZP 2014.

21 Vid. član 166. ZZP 2014.

22 Osnovi za oduzimanje taksativno su navedeni: davanje netačnih podataka; prestanak ispunjenja nekog od uslova; na zahtjev te organizacije; i u slučaju prestanka rada. Vid. član 170. ZZP 2014. 
Pasivno legitimisana lica jesu trgovac pojedinac ili grupe trgovaca iz istog privrednog sektora koje postupaju na opisani način, komorska i interesna udruženja trgovaca koja podstiču takvo postupanje, kao i donosioci različitih kodeksa poslovnog ponašanja kojima se podstiče korišćenje nepoštene poslovne prakse. ${ }^{23}$

Podnošenje tužbe je uslovljeno obaveznim podnošenjem prethodnog pisanog upozorenja da će, u slučaju da ne prekine sa postupanjem kojim se narušavaju kolektivni interesi potrošača, protiv tog lica biti podnijeta kolektivna tužba. Od podnošenja ovog obavještenja mora proteći najmanje 14 dana prije nego što ovlašćeno lice podnese tužbu, dok od suda može odmah tražiti izdavanje privremenih mjera. ${ }^{24}$ Dakle, zahtjev za određivanje privremenih mjera nije uslovljen istekom roka, a odredbama ZZP 2014. predviđeno je da sud može narediti prekid postupanja kojima se narušavaju kolektivni interesi potrošača, ne samo kada trgovac već postupa na određeni način već i u slučaju kada postupanje nije ni počelo, ali je početak takvog postupanja izvjestan. Izvjesnost početka postupanja trgovca mora dokazati tužilac. ${ }^{25}$

Pitanja stvarne i mjesne nadležnosti ovog spora posebno su uređena odredbama ZZP 2014. godine. Stvarno nadležan je sud opšte nadležnosti, dok je mjesno nadležan sud sjedišta tuženog ili njegovog dijela ili poslovne jedinice, ako spor proizilazi iz djelovanja te jedinice. Pitanje mjesne nadležnosti u slučaju kada tuženi nema ni sjedište, dio ni poslovnu jedinicu u Crnoj Gori, određena je alternativno. Mjesno nadležan, u ovom slučaju, može biti stvarno nadležni sud pod čijom je jurisdikcijom područje na kojem je došlo do postupanja koja narušavaju kolektivne interese potrošača ili pod čijom je jurisdikcijom područje na kojem je došlo do nastupanja štetnih posljedica. ${ }^{26}$

Kako postupak za zaštitu kolektivnih interesa potrošača može pokrenuti širok krug aktivno legitimisanih lica, jasno je zašto je zakonodavac posebno uredio pitanja postojeće parnice i srodnih parnica. Tako, nije dozvoljeno pokretanje drugog postupka za zaštitu kolektivnih interesa potrošača u pogledu istog zahtjeva i protiv istog tuženog. Svako drugo aktivno legitimisano lice ima pravo da se pridruži tužiocu u postupku koji je u toku, kao umješač, s tim da ovo lice nema pravo na naknadu troškova. ${ }^{27}$

Postojanje spora za zaštitu kolektivnih interesa potrošača nije smetnja za individualni zahtjev potrošača za naknadu štete, za poništenje ili utvrđivanje ništavosti ugovora koji je zaključen pod uticajem postupanja kojim se narušavaju kolektivni interesi potrošača. Dakle, kolektivna zaštita prava potrošača ne može biti prepreka ostvarivanju individualnih prava, koja potrošač ima na osnovu ZZP 2014. ili bilo kog drugog propisa kojim mu je određeno pravo garantovano. ${ }^{28}$

Pitanja prouzrokovanja štete, vjerovatnoće njenog prouzrokovanja i postojanja krivice za nepoštenu poslovnu praksu, nijesu pitanja kojima će se baviti

23 Član 118. stav 2. ZZP 2014.

24 Član 120. ZZP 2014.

25 Član 128. ZZP 2014. Preduzimanje privremenih mjera vrši se pod uslovima propisanim zakonom kojim se uređuju mjere obezbeđenja.

26 Član 121. ZZP 2014.

27 Član 122. st. 1. i 2. ZZP 2014.

28 Član122. stav 3. ZZP 2014. 
postupajući sud prilikom odlučivanja u slučajevima u kojima je tužba za zaštitu kolektivnih interesa potrošača podnijeta zbog nepoštene poslovne prakse. ${ }^{29}$

U presudi će sud, ukoliko utvrdi povredu prava, precizno opisati način i posljedice povrede i tuženom narediti da prekine sa određenim postupanjem, ${ }^{30}$ zabraniti takvo dalje postupanje, ${ }^{31}$ naložiti objavljivanje odluke ${ }^{32}$ i/ili naložiti ispravku nedopuštenog oglašavanja. ${ }^{33}$ Dakle, iz same sadržine presude jasno je da ZZP 2014. usvaja samo preventivni oblik zaštite potrošača.

Zakonodavac je dao pravo svakom potrošaču, pored tužioca u kolektivnom sporu, da može zahtijevati izvršenje pravosnažne presude u kolektivnom sporu ako za takvo izvršenje ima pravni interes. Posebno je važno naglasiti i to da trgovac koji je bio stranka u postupku po kolektivnoj tužbi gubi pravo da se poziva na takve odredbe iz već ranije zaključenih ugovora, ukoliko sud zabrani korišćenje određenih nepoštenih odredaba u ugovoru. ${ }^{34}$

Posebno su važne i posljedice usvajanja tužbenog zahtjeva u postupku po tužbi za zaštitu kolektivnih interesa potrošača i u odnosu ove odluke i postupka po individualnoj tužbi potrošača za naknadu štete. Ukoliko je individualna tužba podnesena protiv tuženog koji je bio tužen i u kolektivnom postupku, postupajući sud u individualnoj parnici je dužan da odlučuje u skladu sa pravosnažnom odlukom iz postupka za zaštitu kolektivnih interesa potrošača. ${ }^{35}$ Ovim je zakonodavac predvidio mogućnost proširenja subjektivnih granica pravosnažne presude ${ }^{36}$ tako da se u individualnoj parnici odlučuje o postojanju i visini štete, a ne o odgovornosti tuženog za određeno ponašanje.

Veoma je značajno i to da je zakonodavac predvidio uspostavljanje elektronskog javnog registra kako podnijetih kolektivnih tužbi, tako i donijetih odluka. Nadležnost za vođenje registra data je Ministarstvu ekonomije, a sudovima je naložena obaveza dostavljanja tužbe odmah nakon podnošenja i odluke odmah nakon donošenja. ${ }^{37}$

Pitanje finansiranja i troškova postupka je jedno od suštinskih pitanja kolektivne zaštite, s obzirom na dalekosežan uticaj na dostupnost i efikasnost ovog sistema zaštite. Poželjno je da troškovi pokretanja i vođenja sudskih postupaka

29 Koncept nepoštene poslovne prakse, odnosno zabrane te prakse detaljno je regulisan i normativno razrađen u III dijelu ZZP 2014.

30 Sud može narediti tuženom da prekine s postupanjem kojim krši prava potrošača i da, ako je to moguće, preduzme mjere neophodne za otklanjanje štetnih posljedica koje su nastale zbog njegovog postupanja (član 123. stav 1. tačka 1. ZZP 2014).

31 Sud može zabraniti dalje takvo ili slično postupanje kojim se narušavaju kolektivni interesi potrošača (član 123. stav 1. tačka 2. ZZP 2014).

32 Sud može naložiti da o sopstvenom trošku objavi cijelu odluku ili njen dio, ako procijeni da njeno objavljivanje može doprinijeti da se ublaže ili u potpunosti otklone štetne posljedice postupanja kojim su povrijeđena (član 123. stav 1. tačka 3. ZZP 2014).

33 Sud može naložiti da o svom trošku objavi ispravku nedopuštenog oglašavanja, kada je to primjenljivo (član 123. stav 1. tačka 4. ZZP 2014).

34 Član 124. ZZP 2014.

35 Član 126. ZZP 2014.

36 Pavlović, M., 2015, str. 815.

37 Član 127. ZZP 2014. 
budu što je moguće manji, kako bi se donekle poboljšala startna pozicija potrošača u odnosu na privredne subjekte koji ugrožavaju njegova prava, ${ }^{38}$ kao i da ne bi trebalo da primjena pravila parničnog postupka o troškovima odvraća ovlašćene subjekte da vode kolektivne postupke. ${ }^{39}$

S obzirom na to da u Crnoj Gori ne postoji kompenzatorna zaštita, jasno je zašto je ostavljeno da vrijednost spora utvrđuje sud. Ipak, u cilju smanjenja izdataka za vođenje ovog postupka, predviđeno je da najveća vrijednost spora ne može biti veća od 5000 evra, bez obzira na ekonomski značaj spora. Sud može smanjiti vrijednost predmeta spora, vodeći računa o složenosti i obimu spora, broju lica protiv kojih se vodi postupak i značaju tužbenog zahtjeva sa stanovišta javnog interesa. ${ }^{40}$

Kako ZZP 2014. nema drugih odredaba o finansiranju i troškovima postupka, ostaje jedino upućujuća norma ovog zakona na shodnu primjenu pravila odredaba zakona kojim se uređuje parnični postupak i zakona kojim se uređuje izvršenje i obezbjeđenje. Ostaje pitanje da li je ovo rješenje svrsishodno, s obzirom na to da je prva kolektivna tužba pokrenuta sredinom maja 2020. godine? $\mathrm{Da}$ li će organizacija potrošača imati finansijski potencijal da vodi dugotrajni parnični postupak sa neizvjesnim ishodom, iako ZZP 2014. predviđa posebna pravila o finansiranju organizacija potrošača? ${ }^{41}$

U literaturi se ukazuje i na to da su, s obzirom na postojeća pravila o finansiranju postupaka, koja predviđaju opšta pravila parničnog postupka u pogledu oslobođenja stranaka od polaganja predujma za troškove svjedoka, vještaka, uviđaja i sudskih oglasa, ${ }^{42}$ ministarstva i organi državne (ovlašćeni pokretači) u najboljoj poziciji za vođenje postupka i da imaju posebnu odgovornost za izgradnju funkcionalnog sistema zaštite kolektivnih interesa potrošača. Ipak, $u$ istim analizama je ukazano da državni organi (ovlašćeni podnosioci) ne vide podnošenje kolektivne tužbe kao svoju osnovnu dužnost. ${ }^{43}$

\subsection{SLUČAJEVI KOLEKTIVNE ZAŠTITE POTROŠAČA U CRNOJ GORI}

Iako je ovaj instrument zaštite potrošača uveden prije šest godina, do pisanja ovog rada evidentirana je samo jedna kolektivna tužba u navedenom periodu. Vidno medijsko prisustvo organizacije za zaštitu potrošača u Crnoj Gori i aktivnost na edukaciji potrošača nisu do marta ove godine propraćeni podnošenjem kolektivne tužbe.

Uloga Centra za zaštitu potrošača (CEZAP) u prethodnom periodu u tužbama protiv Hipo Alpe Adria banke nije bila zasnovana na primjeni pravila o

38 Evropski parlament - Direktorat za opšte i unutrašnje politike (2011), Overview of existing collective redress schemes in EU Member State, str. 6.

39 Evropski parlament - Direktorat za opšte i unutrašnje politike (2011), str. 9.

40 Član 121. stav 6. ZZP 2014.

41 Član 168. ZZP 2014.

42 Član 162. stav 2. Zakona o parničnom postupku, Sl. list RCG, br. 22/04.

43 Savković, V., Dožić, N., 2018, str. 313 i 323. 
kolektivnoj zaštiti potrošača, već je ova organizacija vodila postupak u ime 300 klijenata koji su sa tom bankom zaključili ugovore o kreditu u švajcarskim francima. Ovaj postupak je posljedica spajanja postupaka primjenom opštih pravila građanskog sudskog postupka. Ipak, medijska izvještavanja su, u svjetlu uvođenja principa kolektivne zaštite, ovu aktivnost prikazivala kao prvu kolektivnu tužbu u crnogorskoj pravnoj istoriji.

U martu 2020. godine, podnijeta je prva kolektivna tužba. CEZAP je ovog puta poveo postupak pozivajući se na ranije opisana pravila kolektivne zaštite protiv dvije banke koje posluju u Crnoj Gori. ${ }^{44} \mathrm{U}$ skladu sa pravilima o podnošenju kolektivne tužbe ovlašćeni podnosilac je uputio upozorenja dvijema bankama u kojima je opisao način kršenja prava potrošača.

Jedno od upozorenja upućeno je Erste banci zbog naplate naknada za gašenje transakcionog računa i platne kartice. Spornim se smatrala naknada koju je ova banka naplaćivala potrošačima za gašenje računa i platnih kartice, što je ovlašćeni podnosilac smatrao suprotnim odredbama Zakona o zaštiti potrošača korisnika finansijskih usluga ${ }^{45}$ pozivajući se na to da je jasno precizirano da potrošač ima pravo na gašenje kartice i transakcionog računa bez naknade. Zakonom je jasno propisano da korisnik ima pravo da bez naknade izvrši gašenje transakcionog računa ${ }^{46}$ i platne kartice. ${ }^{47}$ Kako je ova banka izmijenila svoju odluku o naknadama, nije bilo potrebe za podnošenjem tužbe u ovom konkretnom slučaju.

Drugo upozorenje CEZAP je uputio Crnogorskoj komercijalnoj banci, zbog naplaćivanja naknade zbog prijevremenog vraćanja kredita određene istim procentom. U konkretnom slučaju, ova banka je u svojim aktima predvidjela obavezu korisnika kredita da plati $1 \%$ iznosa kredita koji se prijevremeno otplaćuje ako je period između dana prijevremene otplate i roka dospijeća iz ugovora o kreditu duži od 12 mjeseci ili $0,5 \%$ u slučaju kada je ovaj rok kraći od 12 mjeseci. Ovlašćeni podnosilac smatra da ovakva rješenja nijesu u skladu sa odredbama Zakona o potrošačkim kreditima, ${ }^{48} \mathrm{~s}$ obzirom na to da u oba slučaja kreditor ima pravo na pravednu i objektivnu naknadu opravdanih troškova neposredno povezanih sa prijevremenom otplatom kredita, pod uslovom da je prijevremena otplata izvršena tokom perioda za koji je ugovorena fiksna kamatna stopa. ${ }^{49}$ Iznos ove naknade ograničen je zakonom na iznos koji ne smije biti veći od $1 \%$ i $0,5 \%$ u navedenim slučajevima. Podnosilac smatra spornim činjenicu da banka u svakom pojedinačnom slučaju primjenjuje maksimalan iznos, što ne smatra objektivnom i pravednom naknadom troškova banci. S obzirom na to da je istekao rok od podnošenja upozorenja, ovlašćeni podnosilac je podnio tužbu kojom je tražio prestanak kršenja kolektivnih interesa potrošača u konkretnom slučaju.

44 https://mina.news/mina-business/cezap-pokrenuo-prvu-kolektivnu-tuzbu-protiv-ckb/ 15. 6 . 2020.

45 Zakon o zaštiti potrošača - korisnika finansijskih usluga, Sl. list CG, br. 43/15 (u daljem tekstu: ZZPKFU).

46 Član 34. stav 3. ZZPKFU.

47 Član 35. stav 7. ZZPKFU.

48 Zakon o potrošačkim kreditima, Sl. list CG, br. 35/13 i 73/17 (u daljem tekstu: ZPK).

49 Član 23. ZPK. 
Kako je tužba podnijeta neposredno prije početka epidemije i uvođenja izmijenjenog rasporeda u radu sudova u prethodnom periodu, postupak je još uvijek pred Osnovnim sudom u Podgorici.

Uspjeh u prvom slučaju po upozorenju govori da ovaj mehanizam ima svoje opravdanje i da je već izmijenio način ophođenja trgovaca u potrošačkim sporovima. Ipak, izuzetno značajno bi bilo da ovaj prvi slučaj kolektivne tužbe bude okončan u korist potrošača, jer bi takva odluka u korist potrošača doprinijela boljoj poziciji potrošačkih organizacija koje će biti nosilac kolektivne zaštite potrošača.

\section{PRIJEDLOG DIREKTIVE O UDRUŽNIM TUŽBAMA ZA ZAŠTITU KOLEKTIVNIH INTERESA POTROŠAČA}

Prateći primjenu Preporuke na nivou Unije, urađene analize su pokazale više razlika u nacionalnim sistemima u kolektivnoj zaštiti uopšte.

Preventivna zaštita postoji u svim državama članicama, kao posljedica posebne direktive. Horizontalna zaštita u ovom slučaju postoji samo u pet država, dok je u drugim prihvaćen sektorski pristup. Kompenzatorna zaštita u vidu horizontalnog principa postoji samo u šest država članica, među kojim ima i onih sistema koji pružaju i specifičnu sektorsku zaštitu. ${ }^{50}$ Samo mali broj država je usvojio ili promijenio postojeće zakone u skladu sa principima iz preporuke. Štaviše, čak devet država uopšte ne poznaje sistem kolektivne kompenzatorne zaštite, a u sistemima koji pružaju ovaj vid zaštite, strogi uslovi, duga priroda postupaka i/ili pretpostavljena visina troškova u odnosu na korist čine da se ova sredstva u praksi rijetko koriste. Dakle, studija je pokazala vidnu nejednakost i nedostatke u primjeni evropskog prava u nacionalnim sistemima, tako da je jasno data preporuka za stvaranje minimuma pravila u zaštiti potrošača u građanskim parnicama. ${ }^{51}$

Afera Dizelgejt 2015. godine, otkazivanje letova 2017. godine i dr. ukazali su na nedostajuće mehanizme kolektivne pravne zaštite na nivou Evropske unije, $s$ obzirom na prekogranične slučajeve, razlike u sistemima država članica i nedostajuća pravila međunarodnog privatnog prava. U preporuci nakon afere Dizelgejt Evropski parlament je pozvao Komisiju da donese predlog o usklađenom sistemu pravne zaštite potrošača na temelju najboljih praksi, kako bi se pružila zaštita u mnogim državama članicama koje u svojim sistemima nemaju pravila o kolektivnom ostvarivanju prava potrošača. Uočeno je da se danas potrošači sri-

50 Report from the Commission to the European Parliament, the Council and the European Economic and Social Committee on the implementation of the Commission Recommendation of 11 June 2013 on common principles for injunctive and compensatory collective redress mechanisms in the Member States concerning violations of rights granted under Union law (2013/396/EU), 2018, p. 3, (https://eur-lex.europa.eu/legal-content/EN/TXT/PD$\mathrm{F} /$ ?uri=CELEX:52018DC0040\&from=EN, 20. 6. 2020).

51 Revision of consumer law directives - European Parliament, Revision of consumer law directives (including injunctions): the 'New Deal for Consumers', 2018, p. 5 (https://www.europarl.europa.eu/ RegData/etudes/BRIE/2018/615672/EPRS_BRI(2018)615672_EN.pdf, 20. 6. 2020). 
jeću sa istim problemima prilikom ostvarivanja individualne pravne zaštite kao i prije deset godina, što je uslovljeno dužinom trajanja i nevjericom u uspjeh postupka, prethodnim lošim iskustvima, nesigurnošću u svoja prava, neobaviještenošću o povredama koje su utrvđene i sl. ${ }^{52}$

Najavljeni New Deal za potrošače ima za cilj upravo izmjenu Direktive o preventivoj kolektivnoj zaštiti u cilju stvaranja uslova za efikasnu kolektivnu zaštitu. ${ }^{53}$ U Predlogu Direktive predviđeno je više izmjena. Prvo, izmjene se odnose na područje primjene Direktive i na druge sektore, kao što su: finansijske usluge, energetika, telekomunikacije, zdravstvo i zaštita životne sredine. Drugo, ovlašćeni podnosioci kolektivnih tužbi će morati ispunjavati minimalne uslove u pogledu ugleda, a za kompenzatorne postupke moraće otkriti svoj finansijski potencijal i porijeklo sredstava finansiranja, što će predstavljati dodatnu zaštitu od zlonamjernih tužbi. Treće, države će morati regulisati ekspeditivan sistem (ubrzanog postupka) koji neće stvarati prevelike troškove koji bi bili prepreka pokretanju postupka. Četvrto, predviđaju se i posebna pravila o obavještavanju potrošača o ishodima postupka i načinu ostvarivanja koristi, u cilju jačanja osviješćenosti potrošača i mogućnostima pravne zaštite. Peto, uređuje se i dejstvo konačnih odluka o tome da li je došlo do povrede prava u državi članici (dejstvo neoborivog dokaza) i drugim državama članicama (oboriva pretpostavka o povredi), osim u slučaju deklaratornih odluka o odgovornosti trgovca prema potrošačima zahvaćenima povredom. Šesto, predviđa se širok spektar mjera u postupku, uz određenu fleksibilnost koja se daje državama članicama prilikom razlikovanja slučajeva "male vrijednosti“ i slučajeva u kojima se može identifikovati potrošač, praksa, kao i kada je šteta uporediva. Sedmo, predviđena je mogućnost uvođenja vansudskog postupka za kolektivne nagodbe koje bi odobravali sud ili upravni organi, u postupku ispitivanja njihove zakonitosti i pravednosti, uz pravo potrošača da postignutu nagodbu prihvati ili odbije. Osmo, predviđaju se suspenzivni učinci kolektivne tužbe na zastarne rokove. Deveto, obezbjeđuje se minimalni nivo djelotvornog pristupa informacijama u posjedu trgovca, koje su kvalifikovanim subjektima za podnošenje tužbe potrebni radi dokazivanja svojih tvrdnji ili obavještavanja potrošača o postupku koji je u toku. Deseto, predviđena su posebna pravila o sistemu pomoći kvalifikovanim subjektima i o njihovoj međusobnoj saradnji, kao i pravila o prekograničnom podnošenju kolektivnih tužbi i uzajamno priznavanje statusa kvalifikovanog subjekta među državama članicama. ${ }^{54}$

52 Prijedlog Direktive Europskog parlamenta i Vijeća o udruženim tužbama za zaštitu kolektivnih interesa potrošača i stavljanju izvan snage Direktive 2009/22/EZl, COM/2018/184 final - 2018/0089 (COD), (https://eur-lex.europa.eu/legal-content/HR/TXT/?uri=CELEX\%3A52018PC0184, 20. 6. 2020), str. 2 i 8 (u daljem tekstu: Predlog Direktive).

53 Policy Department for Citizens' Rights and Constitutional Affairs, Collective Redress in the Member States of the European Union, PE 608.829 - October 2018, p. 8, (https://www.europarl.europa.eu/RegData/etudes/STUD/2018/608829/IPOL_STU(2018)608829_EN.pdf, 20. 6. 2020).

54 Prijedlog Direktive Europskog parlamenta i Vijeća o udruženim tužbama za zaštitu kolektivnih interesa potrošača i stavljanju izvan snage Direktive 2009/22/EZl, COM/2018/184 final - 2018/0089 (COD), https://eur-lex.europa.eu/legal-content/HR/TXT/?uri=CELEX\%3A52018PC0184, 20. 6. 202, (u daljem tekstu: Predlog Direktive). 
Bez detaljnog izlaganja novih rješenja sadržanih u direktivi, u želji da ukažemo samo na najnoviji razvoj u ovoj oblasti na nivou Evropske unije, ${ }^{55}$ jasno je da se sistem koji je postavljen u crnogorskom pravu može smatrati nezadovoljavajućim u pogledu usaglašenosti sa Preporukom i naravno reakcijom Evropske unije, u formi Predloga Direktive, stavljene u proceduru upravo sa namjerom da se sistem kolektivne zaštite u EU uredi horizontalnim pravilima u svim oblicima kolektivne zaštite. ${ }^{56}$

\section{PERSPEKTIVE RAZVOJA SISTEMA KOLEKTIVNE ZAŠTITE POTROŠAČA U CRNOJ GORI - UMJESTO ZAKLJUČKA}

Istaknuta kritika nepostojanja horizontalnih pravila kolektivne zaštite prava mora biti osnova budućih zakonodavnih izmjena. Slično, primjera radi, hrvatskom ili zakonodavstvu Srbije prije odluke Ustavnog suda, ova pravila moraju naći svoje mjesto u crnogorskom pravnom sistemu. U periodu od donošenja ZZP 2014. vršeno je nekoliko izmjena teksta ovog zakona, ali pravila o kolektivnoj zaštiti su ostala neizmijenja, uprkos nepostojanju prakse u ovoj oblasti ni nakon šest godina od uvođenja sistema kolektivne zaštite. Iako uvođenje sistema kolektivne zaštite potrošača $\mathrm{u}$ crnogorskom pravu zaista predstavlja pozitivni pomak u normativnoj djelatnosti zakonodavca, ipak je ovaj sistem još uvijek nepotpun i zahtijeva dodatnu aktivnost, uz stalnu edukaciju ovlašćenih podnosilaca tužbi kako bi u potpunosti opravdao očekivanja. S obzirom na neobaveznost Preporuke, može se pretpostaviti zašto crnogorski zakonodavac nije razmatrao potrebu donošenja pravila o kolektivnoj zaštiti potrošača koja je predložena neobavezujućim izvorima prava Evropske unije. Akterima je pružena prilika da se upoznaju sa do sada nepoznatim i netipičnim konceptima zaštite, uvažavajući specifičnosti crnogorskog društva, pravosudnog sistema još uvijek nesklonog da se poziva na odredbe zakona kojima su regulisana prava potrošača, kao i samu svijest potrošača o svojim pravima.

I pored kritika, danas smo svjedoci pokušaja organizacije za zaštitu potrošača u Crnoj Gori da iskoristi i ovaj, ma koliko ograničen mehanizam kolektivne zaštite, u cilju izmjene nedozvoljenog poslovanja trgovaca. Pozitivan ishod prvih sporova će značajno uticati na poimanje ovog oblika zaštite u naučnoj i stručnoj javnosti i na njegovo dalje korišćenje.

Takođe, u svijetlu intenzivnih pristupnih pregovora i intenzivne zakonodavne aktivnosti u cilju usaglašavanja zakonodavstva, nadamo se da će naredne izmjene ZZP2014. ići u korak sa tekstom Predloga Direktive, usvajajući sistem

55 Više vidi: Smith, V., 2019, Redress through collective actions in Europe: ELI/UNIDROIT and European Commission proposals, Uniform Law Review, 1, (https://doi.org/10.1093/ulr/ unz004).

56 Više vid. Hamuláková, K., 2019, The Concept of Locus Standi in Collective Protection of Consumer Rights - the Pitfalls of Transposition of European Model into the Czech Legal Order, International \& Comparative Law Review, 2. 
kompenzatorne zaštite, uz sve novine date u njemu. Ukoliko ona ne bude usvojena u vrijeme izmjena ZZP 2014, s obzirom na to da crnogorski pravni sistem još uvijek pokazuje otvorenost za savremene regulatorne trendove, pa čak i za formalno neobavezujuće sugestije koje nam stižu iz Evropske unije, a da postoji nesumnjiva potreba za daljom harmonizacijom ovih pravila i u jugoistočnoj Evropi, nadamo se da će zakonodavac prilikom pripreme izmjena ovog zakona uvažiti potrebe za neophodnim razvojem i daljom nadgradnjom pravila kolektivne zaštite potrošača. ${ }^{57}$

\section{LITERATURA}

1. Babović, B., 2014, Zaštita kolektivnih interesa potrošača, Anali Pravnog fakulteta u Beogradu, 2, Pravni fakultet Univerziteta u Beogradu.

2. Evropski parlament - Direktorat za opšte i unutrašnje politike (2011), Overview of existing collective redress schemes in EU Member State.

3. Fairgrieve, D. et al., 2018, Collective Redress Mechanisms in Consumer Protection in the European Union and South East Europe: Comparative Study, Deutsche Gesellschaft für Internationale Zusammenarbeit (GIZ) GmbH.

4. Hamuláková, K., 2019, The Concept of Locus Standi in Collective Protection of Consumer Rights - the Pitfalls of Transposition of European Model into the Czech Legal Order, International \& Comparative Law Review, 2.

5. Karanikić, M., 2014, Kolektivna zaštita potrošača u srpskom pravu, Zbornik radova Pravnog fakulteta u Zenici, 14, Pravni fakultet Univerziteta u Zenici.

6. Pavlović, M., 2015, Značaj tužbe za kolektivnu zaštitu interesa i prava, Zbornik radova Pravnog fakulteta u Splitu, 3, Pravni fakultet Univerziteta u Splitu.

7. Policy Department for Citizens' Rights and Constitutional Affairs, Collective Redress in the Member States of the European Union, PE 608.829 - October 2018, (https://www.europarl.europa.eu/RegData/etudes/STUD/2018/608829/IPOL_ STU(2018)608829_EN.pdf, 20.6.2020).

8. Popović, D., 2014, Report: Workshop 'Collective Redress in South-East Europe', European Business Organization Law Review, 15.

9. Preporuka 2013/396/EZ od 11. juna 2013. o zajedničkim načelima o kolektivnim zahtjevima za zabranu postupanja i kolektivnim zahtjevima za naknadu štete, u vezi s povredama prava koja su garantovana pravom Evropske unije.

10. Report from the Commission to the European Parliament, the Council and the European Economic and Social Committee on the implementation of the Commission Recommendation of 11 June 2013 on common principles for injunctive and compensatory collective redress mechanisms in the Member States concerning violations of rights granted under Union law (2013/396/EU), 2018, (https://eur-lex.europa.eu/ legal-content/EN/TXT/PDF/?uri=CELEX: 52018DC0040\&from=EN, 20. 6. 2020).

11. Revision of consumer law directives - European Parliament, Revision of consumer law directives (including injunctions): the 'New Deal for Consumers', 2018, (https://www. europarl.europa.eu/RegData/etudes/BRIE/20 18/615672/EPRS_BRI(2018)615672_EN. pdf, 20. 6. 2020).

57 Popović, D., 2014, Report: Workshop 'Collective Redress in South-East Europe', European Business Organization Law Review, 15, p. 442. 
12. Savković, V., Dožić, N., Collective Redress in Consumer Protection in Montenegro, Collective Redress Mechanisms in Consumer Protection in the European Union and South East Europe - Comparative Study, GIZ, Skopje, 2018.

13. Smith, V., 2019, Redress through collective actions in Europe: ELI/UNIDROIT and European Commission proposals, Uniform Law Review, 1, (https://doi.org/10.1093/ ulr/unz004).

14. Vlada Crne Gore, 2013, Program pristupanja Evropskoj uniji od 2014. do 2018. godine.

\section{PROPISI}

1. Direktiva 2009/22/EZ Europskog parlamenta i Vijeća od 23. aprila 2009. o sudskim nalozima za zaštitu interesa potrošača.

2. Prijedlog direktive Europskog parlamenta i Vijeća o udružnim tužbama za zaštitu kolektivnih interesa potrošača i stavljanju izvan snage Direktive 2009/22/EZl, COM/2018/184 final - 2018/0089 (COD), https://eur-lex.europa.eu/legal-content/ HR/TXT/?uri=CELEX\%3A52018PC0184, (20. 6. 2020).

3. Zakon o obligacionim odnosima, (Sl. list SFRJ, br 29/78, 39/85, 45/89 i 57/89, Sl. list SRJ, br. 31/93 i Sl. list SCG, br. 1/03).

4. Zakon o parničnom postupku (Sl. list RCG, br. 22/04).

5. Zakon o zaštiti potrošača (Sl. list SRJ, br. 37/02).

6. Zakon o zaštiti potrošača (Sl. list RCG, br. 26/07, 40/11, 35/13, 1/14, 14/14).

7. Zakon o zaštiti potrošača (Sl. list CG, br. 2/14, 43/15, 70/17 i 67/19).

8. Zakon o zaštiti potrošača - korisnika finansijskih usluga (Sl. list CG, br. 43/15).

9. Zakon o potrošačkim kreditima (Sl. list CG, br. 35/13 i 73/17).

\section{OSTALI IZVORI}

1. https://mina.news/mina-business/cezap-pokrenuo-prvu-kolektivnu-tuzbu-protiv$\mathrm{ckb} /$ 15. 6. 2020. 


\title{
COLLECTIVE REDRESS IN CONSUMER PROTECTION IN MONTENEGRO \\ - DE LEGE LATA AND DE LEGE FERENDA -
}

\author{
Nikola Dožić
}

SUMMARY

The author deals with the collective redress of consumers in Montenegro. Special attention is paid to the historical origin and development of collective protection in Montenegrin law in general. The development of this institute is examined in the light of the long process of Montenegrin legal system upgrade in the accession negotiations in the chapter dedicated to consumer and health protection, given the fact that the idea of collective redress is a consequence of harmonization of national legislation. The author also gives an overview of cases of collective protection in Montenegrin law. The existing legal framework has been presented, as well as the latest proposal for a European Union directive in this area, which will significantly change the system of collective protection established at the European level. Finally, recommendations were made to amend Montenegrin law, not only in order to harmonize national legislation, but also to create effective mechanisms for this type of protection to achieve its basic purpose.

Key words: collective redress, collective judicial actions, collective out-of-court actions. 